\title{
EFFECT OF COLLECTOR, FROTHER AND DEPRESSANT ADDITION ON THE COPPER RECOVERY AND CONCENTRATE GRADE OF THE NCHANGA UNDERGROUND SCAVENGER CIRCUIT OF KONKOLA COPPER MINE - ZAMBIA
}

\author{
Mpongo, M. K. and Siame, E. \\ University of Zambia, School of Mines, Department of Metallurgy and Mineral Processing \\ P.O. Box 32379, Lusaka, Zambia
}

\begin{abstract}
Nchanga copper ore is a complex mixture of sulphide and oxide minerals and processing involves sulphide flotation and the sulphide rougher/scavenger tails rich in oxide minerals (acid soluble copper) are sent to the Tailings Leach Plant for the recovery of the acid soluble copper. Currently, the acid insoluble copper (sulphides) losses on the scavenger banks are very high, from about $0.3 \%$ TCu to $0.77 \%$ TCu. Mineralogical tests carried out on the scavenger feed samples showed that the valuable minerals were liberated. This indicated that the chemical environment might have an effect on the recovery of the sulphide minerals (acid insoluble copper) lost to the tailings. In this paper the effect of collector, frother and depressant addition on the copper recovery and concentrate grade of the Nchang a Underground Scavenger circuit was studied. The investigation involved the flotation recovery of sulphide minerals from the scavenger feed upon addition of the collector, frother and depressant. The reagent dose rates were varied as follows: collector (10,30, 50 and $80 \mathrm{~g} / \mathrm{t})$, frother $(10,20$, and $30 \mathrm{~g} / \mathrm{t})$, and depressant (40, 60, and $100 \mathrm{~g} / \mathrm{t})$. The results showed that the addition of TDSC 39/R9004A frother (maximum recovery $72.49 \%$ TCu with a concentrate grade of $29.5 \% \mathrm{TCu}$ at a dose rate of $30 \mathrm{~g} / \mathrm{t}$ ) to the scavenger feed is more effective than the addition of SIPX collector (maximum recovery of $23.99 \%$ TCu with a concentrate grade of $26 \%$ TCu at a dose rate of $50 \mathrm{~g} / \mathrm{t}$ ). The depressant (Deptan 100) was more effective at lower dose rate of $40 \mathrm{~g} / \mathrm{t}$ at which the level of insolubles reduced to $35 \%$.
\end{abstract}

Keywords: Sulphide minerals; Mineralogy; Flotation; Collector; Frother; Depressant.

\section{INTRODUCTION}

Nchanga Concentrator treats various ores mined from around Chingola, namely: Nchanga open pit, Luano open pit, Chingola open pit and underground. The Nchanga West Mill Concentrator processes copper from Open pit and Underground mines as well as cobalt from the Open pit.

The West Mill treats copper ore from Underground, at rated milling capacity of about 8,500 tonnes per day. Underground copper ore is a high-grade ore, which occurs in form of sulphide. The average ore grade of Nchanga Underground is $3.50 \% \mathrm{TCu}$.
The ore is milled in ten, 9-inch by 8 -inch mills and the cyclone overflow at a density of 1,280-1,320 gpl is pumped to pre-flotation agitator.

Collector (140 g/t) is added to Ball mills and $20-\mathrm{g} / \mathrm{t}$ collector is added at the agitators to cater for slimes. The material is pumped to rougher bank $\mathrm{C}$ that handles Nchanga Underground material at an average head grade of 3.20 $\% \mathrm{TCu}$. The grade of the rougher concentrate produced ranges from 15 to $20 \% \mathrm{TCu}$.

The concentrate from rougher bank $\mathrm{C}$ gravitates into pump boxes enroute to 80 -ft thickener. The thickener underflow is pumped to 72 -inch and 8 -inch columns. The final 
Effect of Collector, Frother and Depressant Addition on the Copper Recovery and Concentrate Grade of the Nchanga Underground Scavenger Circuit of Konkola Copper Mine - Zambia

concentrate of $44 \% \mathrm{TCu}$ grade and above is obtained from these columns.

The tailings from the 72-inch and the 8-inch columns are the feed to the Scavenger banks (710 to 712 banks). The concentrates from the Scavenger banks are pumped back to 80 -inch thickener. The tailings from scavenger banks go as final tailings to the Tailings Leach Plant, for the recovery of the acid soluble copper.

Currently, AICu (Acid Insoluble Copper) losses on the $710-712$ sulphide scavenger banks are very high (from $0.3 \% \mathrm{TCu}$ to $0.77 \% \mathrm{TCu}$ ), as a result it was of necessity to evaluate the effect of reagent (collector, frother and depressant) addition to the scavenger circuit so as to improve on recovery and the concentrate grade and hence minimise copper losses to tailings. Mineralogical tests carried out on the scavenger feed samples showed that the minerals were liberated. This indicated that the reason for the acid insoluble copper losses to the tailings had to do with the pulp chemistry.

In order to produce optimum conditions for highly selective and efficient flotation process, various flotation reagents are added. In practice, flotation is almost impossible without the use of flotation reagents. Flotation reagents alter the surface properties of minerals over a range and make the mineral particles water-avid or waterrepellent. A great variety of flotation reagents are used, which differ in composition. Common reagents employed are organic and inorganic compounds, acids and alkalis, various salts, water-soluble substances, and materials practically insoluble in water. The reagents used may be broadly classified as collectors, frothers, and modifiers (regulators) according to their function in flotation.

The objective of this work was to optimise the flotation conditions as well as study the effect of:

a) Frother addition on the Nchanga Underground Scavenger Circuit (Dosage- 10, 20, 30 g/t only);

b) Collector addition on the Nchanga Underground Scavenger Circuit (Dosage- 10, 30, 50, $80 \mathrm{~g} / \mathrm{t}$ only);

c) Depressant addition on the Nchanga Underground Scavenger Circuit (Dosage- 40, 60, $100 \mathrm{~g} / \mathrm{t}$ only).

\section{EXPERIMENTAL}

About 100 litres of slurry was collected from the Scavenger Circuit Feed Sump with a pulp density of $1130 \mathrm{~g} / 1$ (22\% solids). Prior to laboratory test-work the sample was thoroughly mixed using a sample splitter. The split sample was then transferred into 2 litre flotation cells and then onto the Denver flotation machine. A control sample was evaluated without addition of any reagents and keeping all other variables constant.

The flotation experiments were performed in a 2-litre laboratory Denver flotation cell. The speed of the impeller was 1,200 r.pm. The laboratory flotation circuit is shown in Figure 1. The reagents used were:

Collector - Sodium Isopropyl Xanthate (SIPX) at dosages of $10,30,50$ and $80 \mathrm{~g} / \mathrm{t}$ of ore, conditioned for 2 minutes.

Frother - TDSC 39 and R9004A at dosages of 10, 20, and $30 \mathrm{~g} / \mathrm{t}$ of ore, conditioned for 1 minute.

Depressant - Deptan 100 at dosages of 40, 60, and $100 \mathrm{~g} /$ t of ore, conditioned for 1 minute.

Each reagent was studied separately.

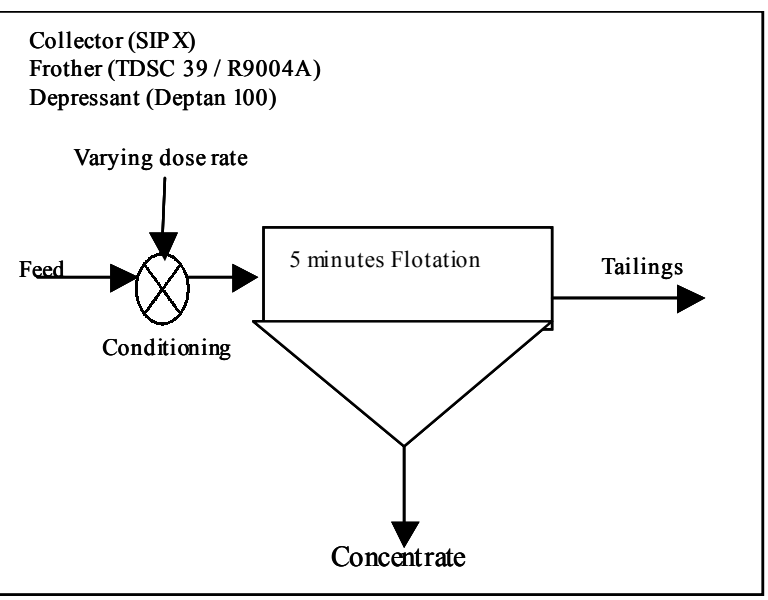

Figure 1: Laboratory Flotation Flowsheet

The samples of the feed, concentrates and tailings were analysed for percent Total Copper ( $\% \mathrm{TCu})$, and percent Acid Soluble Copper (\%ASCu). Percent Insoluble (\%Insols) were analysed in the feed and in the concentrates for the evaluation of the depressant, Deptan 100 . 


\section{RESULTS}

\section{Frother Evaluation}

Figure 2 shows the variation of recovery/concentrate grade with TDSC 39/R9004A frother dosage. It can be observed that the maximum cumulative recovery was $72.49 \% \mathrm{TCu}$ $(79.06 \% \mathrm{AICu})$ and a concentrate grade of $31.04 \% \mathrm{TCu}$ at a frother (TDSC 39/R9004A) dosage of $30 \mathrm{~g} / \mathrm{t}$. As seen from the graph, increasing frother dose rate increased the recovery but decreased the concentrate grade.

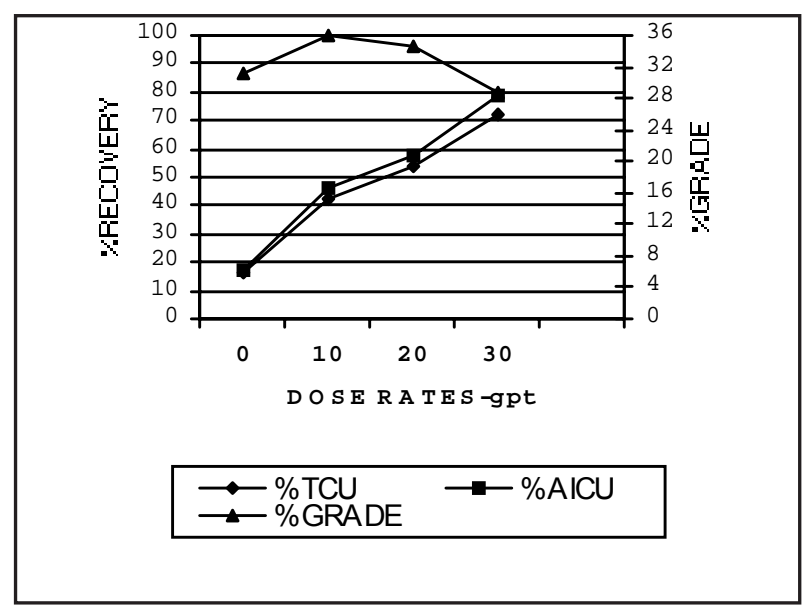

Figure2: Recovery/Grade versus Frother Dose Rate

\section{Collector Evaluation}

Figure 3 shows the variation of recovery/concentrate grade with collector dosage. It can be observed that the maximum cumulative recovery was $24.04 \% \mathrm{TCu}(25.60 \% \mathrm{AICu})$ and a concentrate grade of $29.90 \% \mathrm{TCu}$ at a collector dosage of $80 \mathrm{~g} / \mathrm{t}$. It can be seen from the figure that beyond the collector dose rate of $30 \mathrm{~g} / \mathrm{t}$, the recovery of the acid insoluble copper was almost constant.

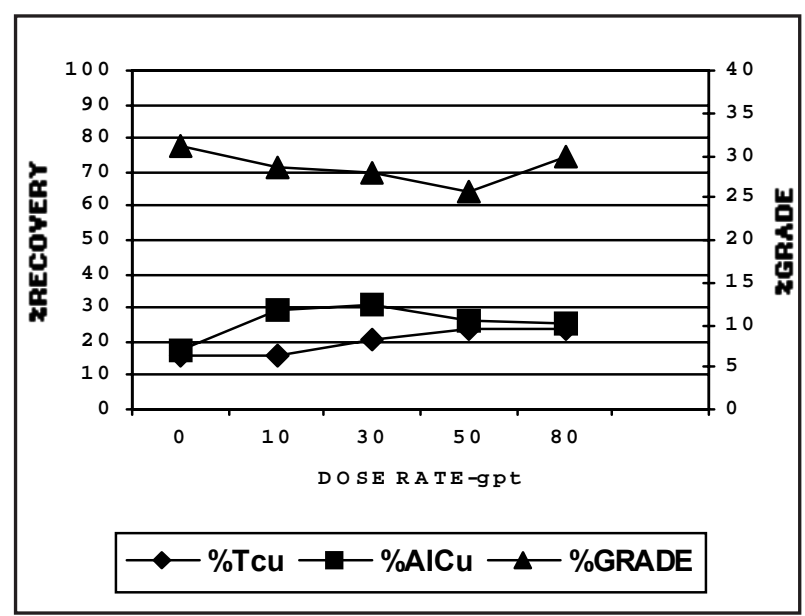

Figure 3: Recovery/Grade versus Collector dose rate

\section{Depressant Evaluation}

Figure 4 shows the graph of percent Insoluble against Deptan 100 depressant dose rate. It can be seen from the figure that, as the depressant dose rate increases beyond $40 \mathrm{~g} / \mathrm{t}$, the percent insols were rising. Table 1 shows the variation of concentrate recovery, grade and percent insoluble with Deptan 100 depressant dosage. It can be observed that the maximum cumulative recovery was 25.47 $\% \mathrm{TCu}(27.28 \% \mathrm{AICu}, 35.45 \%$ Insol $)$ and a concentrate grade of $30.75 \% \mathrm{TCu}$ at a depressant (Deptan) dosage of $40 \mathrm{~g} / \mathrm{t}$.

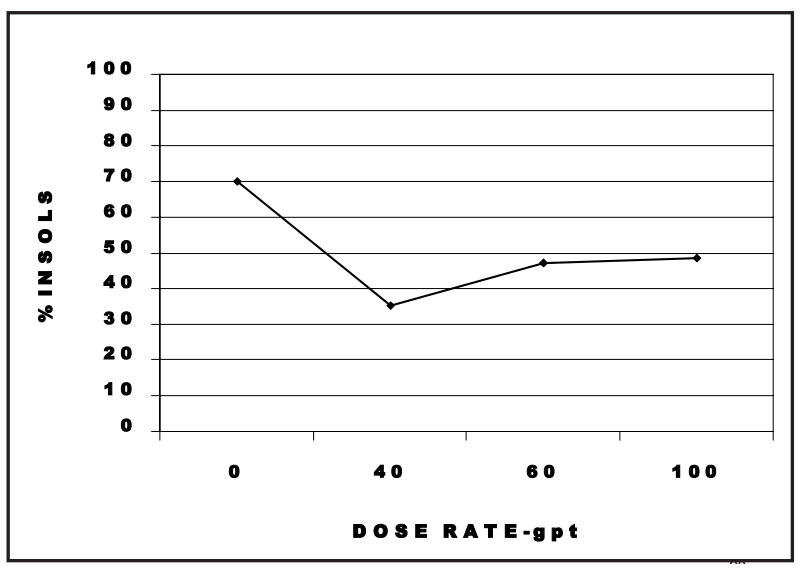

Figure 4: \% Insols versus Depressant dose rate

Table 1: Results for Depressant Deptan 100 Evaluation

\begin{tabular}{|c|c|c|c|c|c|}
\hline \multirow{3}{*}{$\begin{array}{l}\text { Depressant } \\
\text { Deptan } 100 \\
\text { (g/t) }\end{array}$} & \multicolumn{5}{|c|}{ Concentrate } \\
\hline & \multicolumn{2}{|c|}{ Recovery } & \multicolumn{2}{|c|}{ Grade } & \multirow{2}{*}{$\begin{array}{c}\% \\
\text { Insoluble }\end{array}$} \\
\hline & $\% \mathrm{TCu}$ & $\% \mathrm{AICu}$ & $\% \mathrm{TCu}$ & $\% \mathrm{AICu}$ & \\
\hline 0 & 16.13 & 17.47 & 32.18 & 29.69 & 68.90 \\
\hline 40 & 25.47 & 27.28 & 30.75 & 28.85 & 35.45 \\
\hline 60 & 22.37 & 23.28 & 19.15 & 17.35 & 47.15 \\
\hline 100 & 15.54 & 15.97 & 21.00 & 19.23 & 48.6 \\
\hline
\end{tabular}

\section{DISCUSSION}

The recoveries of the ASCu were low meaning that much of the recovery was AICu. Therefore the sulphide minerals responded more favourably to the flotation conditions. Much of the oxide minerals were thus lost to the final tailings.

For collector evaluation, it was observed that the cumulative recoveries for $\mathrm{TCu}$ were low at lower collector dosages. This is because at lower concentrations, the amount of collector is insufficient to coat and/or react with all the mineral surfaces available and render them hydrophobic; thereby leaving most of the valuable minerals unfloated, and are thus lost as final tailings. 
Effect of Collector, Frother and Depressant Addition on the Copper Recovery and Concentrate Grade of the Nchanga Underground Scavenger Circuit of Konkola Copper Mine - Zambia

Above a dose rate of $50 \mathrm{~g} / \mathrm{t}$ the graph (Fig.3) shows no significant change in the cumulative recoveries. This is due to the fact that an excessive concentration of the collector has an adverse effect on the recovery of the valuable minerals due to the development of multi-layers on the mineral particles, which reduce the proportion of hydrocarbon radicals oriented into the bulk solution [Wills, 1988; Crozier, 1992]. The hydrophobicity of the mineral particles is thus reduced and hence, their floatability.

The frother was added to permit the production of a sufficiently stable froth to hold the floating mineral particles until the froth is removed from the flotation cell, to reduce surface tension and effect bubble dispersion [Will, 1988]. It was observed that the cumulative recoveries for $\mathrm{TCu}$ increased with an increase in frother dose rates. With low frother concentration, effect of bubble dispersion is more effective, whereas increased concentrations assist coalescence and are thus undesirable. It would not be economical to consider higher dosages. Frother costs as much as $\$ 1.08$ per $\mathrm{kg}$ for oxide frother (R9004A) and \$0.923 per kg for sulphide frother (TDSC 39).

The properties of various frothers used in flotation systems have been studied by Wrobel (1953), Bartsch (1925), Madigan (1972) and Sun (1952, 1953) and reviewed by Booth ad Freyberger (1962. In general, the frothingpower and froth stability rise dramatically as the frother concentration is increased to about $20 \mathrm{ppm}$. Thereafter, a very much smaller increase in froth stability is observed as the concentration increases. At very high concentration, in the case of the frothers of limited solubility, the froth stability decreases.

The results obtained from the evaluation of Deptan 100 depressant, showed that at lower dose rates cumulative recoveries of TCu are higher and insolubles are lower than at higher dose rates. It can be observed that as recovery decreases the concentrate grade also decreases with an increase in the dose rate. This is because these chemicals render a mineral surface inactive to a collector and thus mineral becomes unfloatable by forming a coating on them. By using large amounts of depressant all minerals can be completely depressed but selectivity is achieved by feeding them in small amounts, therefore effectiveness depends on the concentration of the depressant [Jain, 2001].

\section{CONCLUSION}

Stage addition of reagents often yields higher recoveries at substantially lower cost than if all reagents are added at the same point in the Circuit prior to flotation.

From the results obtained it can be concluded that the effect of reagent addition is more pronounced in the evaluation of frother (30g/t frother (TDSC 39/R9004A)), which gave a recovery of $72.49 \% \mathrm{TCu}(79.06 \% \mathrm{AICu})$ and a concentrate grade of $29.5 \%$. Economically $20 \mathrm{~g} / \mathrm{t}$ of Frother would be the most appropriate dosage to employ on the Scavenger Circuit. The level of insolubles can be reduced at lower dosages of depressant ( $40 \mathrm{~g} / \mathrm{t}$ of Deptan 100 ) to about $35.45 \%$ Insols.

Furthermore, frother addition, at $30 \mathrm{~g} / \mathrm{t}$ to the Underground Scavenger circuit improves copper recovery and the concentrate grade.

\section{REFERENCES}

Bartsch, O. (1975) Foaming power and surface tension. Kolloidchem. Beihefte, vol. 20, p.1.

Booth, R.B. and Freyberger, W.L. (1962) Froths and frothing agents. In Froth Flotation, edit. D.W. Fuerstenau. AIME, New York, p. 258.

Crozier R.D., (1992) Flotation: theory, reagents and ore testing, Pergamon Press.

Jain, S.K. (2001) Mineral Processing, $2^{\text {nd }}$ Edition, CBS publishers and distributors.

Madigan, D.C. (1972) Notes on the testing of flotation frothers. Amdel Bull., vol. 13, p. 41.

Sun S.C. (1953) Frothing characteristics of cresylic acids in flotation. Trans. Inst. Min. Metall., vol. 62, p. 301.

Sun, S.C. (1962) Frothing characteristics of pine oil in flotation. Trans. AIME, vol. 193, p. 65.

Wills, B.A. (1998) Mineral Processing Technology, Pergamon Press, $5^{\text {th }}$ edition.

Wrobel, S.A. (1953) Power and stability of flotation frothers. Mine and Quarry Eng., vol. 19, p. 314. 